\title{
Contribution of p53-Dependent Caspase Activation to Neuronal Cell Death Declines with Neuronal Maturation
}

\author{
Mark D. Johnson, Yoshito Kinoshita, Hong Xiang, Saadi Ghatan, and Richard S. Morrison \\ Department of Neurological Surgery, University of Washington School of Medicine, Seattle, Washington 98195-6470
}

Caspases play a pivotal role in neuronal cell death during development and after trophic factor withdrawal. However, the mechanisms regulating caspase activity and the role played by caspase activation in response to neuronal injury is poorly understood. The tumor suppressor gene p53 has been implicated in the loss of neuronal viability caused by excitotoxic and DNA damaging agents. In the present study we determined if p53-mediated neuronal cell death required caspase activation. DNA damage increased caspase activity in both cultured embryonic telencephalic and postnatal cortical neurons in a p53dependent manner. Caspase inhibitors protected embryonic telencephalic neurons, but not postnatal cortical neurons, from DNA damage-induced cell death as measured by direct cell counting and annexin $\mathrm{V}$ staining. In marked contrast to the caspase inhibitors, an inhibitor of the DNA repair enzyme, poly(ADP-ribose) polymerase, conferred significant protection from genotoxic and excitotoxic cell death on postnatal cortical neurons but had no effect on embryonic neurons. Glutamatemediated excitotoxicity in postnatal neurons was not associated with measurable changes in caspase activity, consistent with the failure of caspase inhibitors to prevent cell death under these conditions. Moreover, adenovirus-mediated overexpression of p53 killed embryonic and postnatal neurons without activating caspases. Thus, p53-mediated neuronal cell death may occur via both caspase-dependent and caspaseindependent pathways. These results demonstrate that p53 is required for caspase activation in response to some forms of neuronal injury. However, the relative importance of caspase activation in neurons depends on the developmental status of the cell and the specific nature of the death stimulus.

Key words: apoptosis; caspase; DNA damage; excitotoxicity; neuronal cell death; p53
Cell survival is regulated by a complex network of interacting checkpoints composed of both positive and negative effectors. Certain members of the Bcl-2 family of cell death regulators have been identified that inhibit cell death, whereas other members of this family promote cell death (Reed, 1997). Members of the interleukin-1 $\beta$-converting enzyme (ICE)/CED-3 family of cysteine proteases (caspases) also have been implicated as cell death effectors in both vertebrate and invertebrate cells (Cohen, 1997; Nicholson and Thornberry, 1997; Porter et al., 1997; Cryns and Yuan, 1998). Caspases are activated by many different apoptotic stimuli, leading to specific cleavage of a range of cellular protein substrates (Ashkenas and Werb, 1996; Cohen, 1997; Nicholson and Thornberry, 1997; Porter et al., 1997; Cryns and Yuan, 1998). In neurons there is considerable evidence that caspase activity plays an important role in cell death during development (Milligan et al., 1995) and after trophic factor withdrawal (Rabizadeh et al., 1993; Gagliardini et al., 1994; Martinou et al., 1995; Deshmukh et al., 1996; Posmantur et al., 1997; Troy et al., 1997), potassium deprivation (Nath et al., 1996; Schulz et al., 1996; Eldadah et al., 1997; Lynch et al., 1997), oxygen-glucose deprivation (Gottron et al., 1997), and staurosporine treatment (Keane et al., 1997). Developmental cell death in the mouse brain is

\footnotetext{
Received Nov. 18, 1998; revised Feb. 2, 1999; accepted Feb. 3, 1999.

This work was supported in part by National Institutes of Health Grants NS31775 and AG 10917 to R.S.M. We gratefully acknowledge Paul Schwartz and Janet Schukar for their photographic assistance and Chizuru Kinoshita for her technical expertise.

M.D.J. and Y.K. contributed equally to this study.

Correspondence should be addressed to Dr. Richard Morrison, Department of Neurological Surgery, University of Washington School of Medicine, Box 356470, Seattle, WA 98195-6470.

Copyright (C) 1999 Society for Neuroscience $\quad 0270-6474 / 99 / 192996-11 \$ 05.00 / 0$
}

decreased in the absence of caspase-3 (CPP32; Kuida et al., 1996) or caspase-9 (Hakem et al., 1998; Kuida et al., 1998), suggesting that caspases are essential to the regulation of developmental cell death in neurons. In the postdevelopmental period, caspases have been associated with cell death in response to traumatic brain injury (Yakovlev et al., 1997), transient focal cerebral ischemia (Loddick et al., 1996; Friedlander et al., 1997b; Hara et al., 1997a,b), and excitotoxicity (Jordan et al., 1997a; Tenneti et al., 1998).

In neurons, DNA damage and excitotoxicity also can lead to cell death via mechanisms that involve the activation of p53 $(\mathrm{H}$. Xiang et al., 1996, 1998). We have investigated the molecular components of p53-dependent cell death pathways in neurons and have identified an important role for the proapoptotic protein, Bax, in p53-mediated neuronal cell death after DNA damage or excitotoxicity (Xiang et al., 1998). Although the exact mechanism by which Bax promotes cell death is not known, several studies have suggested that Bax may cooperate with bcl-2 or bcl- $\mathrm{X}_{\mathrm{L}}$, or it may act independently to regulate the activation of caspases (J. G. Xiang et al., 1996; Vekrellis et al., 1997; Martinou et al., 1998; Marzo et al., 1998). This suggested that caspases may be associated with a p53-mediated Bax-dependent cell death pathway. We therefore examined whether caspases are activated in neurons after injury in a p53-dependent manner and, if so, whether such activation is essential for p53-dependent neuronal cell death. We report here that DNA damage induced caspase activation in embryonic and postnatal cortical neurons in a p53-dependent manner, but the significance of this activation for cell death was dependent on the stage of neuronal maturation. Caspase inhibitors suppressed DNA damage-induced death of SH-SY5Y neuroblastoma cells and embryonic telencephalic neurons, but not 
postnatal cortical neurons, in culture. In contrast to DNA damage, glutamate-mediated excitotoxicity in postnatal cortical neurons was not associated with caspase activation, consistent with the failure of caspase inhibitors to protect neurons from glutamate-induced cell death. These findings suggest that p53 mediates neuronal cell death after injury via both caspasedependent and caspase-independent pathways. Surprisingly, the relative contribution of caspase activation to cell death was dependent on the state of neuronal maturation, a finding that may help to explain the differential sensitivity of embryonic versus mature neurons to a variety of injuries.

\section{MATERIALS AND METHODS}

Materials. Benzyloxycarbonyl-Val-Ala-Asp(OMe)-fluoromethylketone (zVAD-fmk), z-Asp-Glu-Val-Asp-fmk (zDEVD-fmk), boc-aspartyl(OMe)-fluoromethylketone (BAF), and the fluorogenic caspase substrate zDEVD-AFC were purchased from Enzyme Systems Products (Livermore, CA). Staurosporine was obtained from ICN Pharmaceuticals (Costa Mesa, CA). A cell lysis buffer for fluorogenic caspase activity assays was obtained from Clontech (ApoAlert CPP32 Assay Kit; Palo Alto, CA).

Cell culture. p53-deficient mice were generated from a $129 / \mathrm{Sv} \times$ C57BL/6 background as described (Donehower et al., 1992). The genotypes of the mating pairs and all offspring were determined by PCR, using DNA extracted from the tail (Timme and Thompson, 1994). $\mathrm{p} 53^{-1-}$ mice were generated routinely from $(+/-) \times(-/-)$ mating pairs, whereas p53 wild-type mice were obtained by crossing $\mathrm{p} 53^{+/+}$ mice. The brains from individual animals were cultured separately and genotyped before treatment.

Neuronal cultures derived from embryonic day 14.5 (E14.5) telencephalon or postnatal day $0(\mathrm{P} 0)$ cortex were established as previously described (H. Xiang et al., 1996, 1998). Briefly, embryonic or newborn mice were decapitated, and the telencephalon or the cortex was dissected free in HBSS. Then the dissected tissues were treated with trypsin for 20 min, washed, and dissociated by trituration. The cells were plated on a poly-D-lysine-coated substrate in Neurobasal medium plus B27 supplements (Life Technologies, Gaithersburg, MD) (Brewer et al., 1993) either at $1.25 \times 10^{5}$ cells (postnatal) or $1 \times 10^{5}$ cells (embryonic) per 15 $\mathrm{mm}$ well for neuronal counting, morphological analyses, and annexin $\mathrm{V}$ binding or at $1.5-2 \times 10^{6}$ cells $/ 60 \mathrm{~mm}$ dish for Western blotting and caspase activity assays. The cultures were maintained at $37^{\circ} \mathrm{C}$ in a $5 \%$ $\mathrm{CO}_{2}$ atmosphere. Cultures maintained under these conditions were shown previously to contain $>95 \%$ neurons, as determined by cell morphology and immunocytochemistry for neurofilament and glial fibrillary acidic protein (GFAP) (H. Xiang et al., 1996).

Neurons were maintained routinely in culture for $4 \mathrm{~d}$ before treatment (i.e., camptothecin, glutamate, staurosporine, or adenovirus infection). At specific times after treatment the cells were counted, stained with annexin V, or collected by being scraped in cold PBS, centrifuged, and lysed in an appropriate buffer for Western blotting or caspase activity assays.

Astrocyte cultures were established from newborn mice (P0) as described (Morrison and deVellis, 1981) and were used within two to three passages. Astrocytes were subcultured by trypsinization as previously described (Morrison and deVellis, 1981) and were plated at $2.0 \times 10^{5}$ cells $/ 60 \mathrm{~mm}$ dish. At $5 \mathrm{~d}$ after plating the astrocytes were collected for Western blotting as described above for the neurons.

SH-SY5Y human neuroblastoma cells were obtained from American Type Tissue Culture Collection (Rockville, MD) and were maintained routinely in DMEM/F12 medium with $10 \%$ fetal bovine serum. SHSY5Y cells were plated at $1.25 \times 10^{5}$ cells $/ 15 \mathrm{~mm}$ well for analysis of viability with the live/dead cell assay or at $1.0 \times 10^{6}$ cells $/ 60 \mathrm{~mm}$ dish for Western blots or caspase activity measurements. SH-SY5Y cells were cultured routinely for $2 \mathrm{~d}$ before treatment. At specific times after treatment the cells were analyzed by the live/dead cell assay or collected by being scraped in cold PBS, centrifuged, and lysed in an appropriate buffer for Western blotting or caspase activity assays.

Assessment of neuronal viability. The number of viable neurons was determined by counting cells within four premarked reticules $\left(1 \mathrm{~mm}^{2} /\right.$ well) at the time of treatment and at various times after treatment. Viable neurons were identified according to the following criteria: (1) neurites were uniform in diameter, smooth in appearance, and at least twice as long as the soma; (2) somata were normally smooth and round to oval-shaped; (3) nuclei were normal in appearance, without evidence of condensation or fragmentation. In contrast, degenerating, nonviable neurons possessed neurites that were fragmented and "beaded," and the somata were rough, shrunken, vacuolated, and irregularly shaped. The nuclei of nonviable neurons often were condensed or fragmented.

Cell viability also was evaluated by a live cell/dead cell assay, using two fluorescent probes. Living cells were detected by using calcein-AM (Molecular Probes, Eugene, OR), a fluorogenic esterase substrate that is hydrolyzed to a green fluorescent product and retained by cells with an intact membrane. Dead or dying cells were identified by the uptake of ethidium homodimer-1 (Molecular Probes), a red nuclear dye that is taken up only by dying cells with permeant membranes. At $24 \mathrm{hr}$ after treatment the cells were incubated for $30 \mathrm{~min}$ at room temperature in a solution containing calcein-AM (4 $\mu \mathrm{M})$ and ethidium homodimer-1 (2 $\mu \mathrm{M})$ and subsequently were viewed under epifluorescence, using standard fluorescein and rhodamine filter sets.

Annexin $V$ staining. Embryonic telencephalic and postnatal cortical neurons were cultured for $4 \mathrm{~d}$ and then treated with DMSO, camptothecin $(1 \mu \mathrm{M})$, or camptothecin plus zVAD-fmk $(20 \mu \mathrm{M})$. The culture medium was replaced $8 \mathrm{hr}$ later with the annexin $\mathrm{V}$ staining solution (1 $\mu \mathrm{g} / \mathrm{ml}$ of annexin V-FITC in the binding buffer supplied by the manufacturer; ApoAlert Annexin V apoptosis detection kit, Clontech). After $20 \mathrm{~min}$ of incubation at room temperature the cultures were washed twice with PBS and fixed with 4\% paraformaldehyde in PBS for $20 \mathrm{~min}$. This was followed by two additional washes with PBS. The cultures were observed under an inverted fluorescence microscope and photographed on color slide film with identical exposure conditions. Then the images were scanned into a computer, collated, and printed with Adobe PhotoShop.

Adenovirus preparation. Replication-incompetent adenoviruses with deletions in the E1 region were used for these studies. The p53 adenovirus carrying the human p53 gene under control of the cytomegalovirus (CMV) promoter (Zhang et al., 1993) was the generous gift of $\mathrm{T}$. Fujiwara (Okayama University Medical School, Japan). The adenovirus containing the $\beta$-galactosidase gene (AxCaLacZ; Kanegae et al., 1995) was the gift of Drs. I. Saito and Y. Kanegae (University of Tokyo, Japan). The adenoviruses were propagated in E1-complementing human embryonic kidney 293 cells, purified on cesium chloride gradients, and titrated according to the method of Barr et al. (1995). Cultures were transfected at a multiplicity of infection (MOI) of 250 .

Western blotting. Neurons, astrocytes, and SH-SY5Y cells were lysed in extraction buffer containing $50 \mathrm{~mm}$ Tris- $\mathrm{HCl}, \mathrm{pH} 7.4,150 \mathrm{~mm} \mathrm{NaCl}, 1 \%$ sodium deoxycholate, $0.1 \%$ SDS, $1 \%$ Triton $\mathrm{X}-100$, and the protease inhibitors leupeptin $(5 \mu \mathrm{g} / \mathrm{ml})$, phenylmethylsulfonylfluoride $(1 \mathrm{~mm})$, pepstatin $(7 \mu \mathrm{g} / \mathrm{ml})$, and aprotinin $(5 \mu \mathrm{g} / \mathrm{ml}$; Boehringer Mannheim, Indianapolis, IN). Aliquots were taken for protein determinations with the Bio-Rad protein assay kit (Hercules, CA). Cell extracts containing an equivalent amount of protein $(50 \mu \mathrm{g})$ were boiled for $5 \mathrm{~min}$ in sample buffer containing 5\% 2-mercaptoethanol and 2\% SDS, and the proteins were separated by SDS-PAGE on $12 \%$ precast polyacrylamide gels (Bio-Rad).

Protein then was transferred to nitrocellulose membranes. The membranes were blocked with PBS containing 5\% nonfat dry milk and were incubated overnight at room temperature with a rabbit anti-caspase-2 (Nedd2) polyclonal antibody [1:100; rabbit anti-Nedd2 polyclonal antibody against the $\mathrm{C}$ terminus (C20), number sc-626 (Santa Cruz Biotechnology, Santa Cruz, CA)] or a mouse anti-caspase-3 (CPP32) monoclonal antibody (1:500; mouse anti-CPP32 monoclonal antibody, Transduction Laboratories, Lexington, KY). Blots were washed once with PBS, twice in $0.05 \%$ Nonidet P-40/PBS, and once more in PBS for 10 min each. The blots subsequently were incubated with a biotin-conjugated horse antimouse (Vector Laboratories, Burlingame, CA) or goat anti-rabbit (Jackson ImmunoResearch Laboratories, West Grove, PA) IgG secondary antibody (1:500) for $2 \mathrm{hr}$ at room temperature. The blots were washed as previously described and incubated with an avidin-biotinylated horseradish peroxidase complex (Vectastain Elite ABC, 1:50; Vector Laboratories) in 5\% nonfat dry milk in PBS for $1 \mathrm{hr}$ at room temperature. Then the blots were washed four times as described above. Immunoreactive bands were visualized with the SuperSignal chemiluminescent substrate (Pierce, Rockford, IL) according to the manufacturer's specifications. After a 10 min incubation in the chemiluminescent substrate, the blots were exposed to radiographic film (Hyperfilm ECL, Amersham, Arlington Heights, IL). Molecular weights were determined by comparison with biotinylated molecular weight markers (Bio-Rad). 
Fluorogenic caspase assays. Caspase activity was determined by monitoring the cleavage of a specific fluorogenic caspase substrate, zDEVDAFC (z-Asp-glu-val-asp-7-amino-4-trifluoromethyl coumarin). The various cell types were plated and maintained as described above. At specific times after treatment the cells were collected by being scraped in cold PBS, centrifuged (2000 rpm for $8 \mathrm{~min}$ ), and lysed on ice for $10 \mathrm{~min}$ in the cell lysis buffer provided in the Clontech ApoAlert CPP32 Assay Kit. The extracts were frozen and maintained at $-20^{\circ} \mathrm{C}$ until the time of assay. At that time the extracts were thawed and reacted with the fluorogenic caspase substrate (zDEVD-AFC; $100 \mu \mathrm{M}$ ) in reaction buffer (0.1 M HEPES buffer, $0.1 \%$ CHAPS, and $1 \%$ sucrose, $\mathrm{pH} 7.4$ ) containing DTT $(1 \mathrm{~mm})$. The mixtures were maintained in a water bath at $37^{\circ} \mathrm{C}$ for $40 \mathrm{~min}$ and subsequently were analyzed in a fluorometer (Perkin-Elmer, Emeryville, CA) equipped with a $400 \mathrm{~nm}$ excitation filter and a $505 \mathrm{~nm}$ emission filter. The levels of relative fluorescence were normalized against the protein concentration of each extract, which was determined by using the Bio-Rad Protein Assay reagent. Rabbit IgG was used as a protein standard.

\section{RESULTS}

\section{DNA damage induces caspase activity in a p53-dependent manner}

The application of the topoisomerase I inhibitor, camptothecin, was shown previously to produce widespread neurite fragmentation, nuclear condensation, and cell death in postnatal wild-type cortical neurons within $24 \mathrm{hr}$ after treatment, whereas neurons lacking both p53 alleles were resistant to the effects of camptothecin (Xiang et al., 1998). To determine whether caspases were activated in neurons after DNA damage, we exposed human SH-SY5Y neuroblastoma cells, murine embryonic telencephalic neurons, or murine postnatal cortical neurons to camptothecin, and we evaluated cellular extracts for the presence of caspase activity by monitoring the cleavage of the fluorogenic caspase substrate, zDEVD-AFC. Under control conditions (DMSO treatment, vehicle control for camptothecin) basal levels of caspase activity were detected readily in all three cell types. Caspase activity increased more than threefold in SH-SY5Y cells and in embryonic and postnatal cortical neurons after exposure to camptothecin (Fig. 1). This increase first was detected between 4 and $6 \mathrm{hr}$ after treatment (data not shown) and was inhibited completely by the cell-permeable irreversible caspase inhibitor zVAD-fmk (20 $\mu \mathrm{M})$ (Fig. 1). Maximum inhibition of DEVDcleavage activity was obtained at concentrations $\geq 10 \mu \mathrm{M}$ zVADfmk (data not shown). The results of this study indicated that embryonic and postnatal neurons contained inducible caspase activity that increased in response to genotoxic damage.

The presence of DEVD cleavage activity was consistent with the identification of caspase protein in cellular extracts prepared from human SH-SY5Y neuroblastoma cells, murine embryonic telencephalic neurons, or murine postnatal cortical neurons. Western blot analysis of embryonic and postnatal neurons demonstrated the presence of significant levels of caspase-2 protein, whereas caspase-3 protein was identified readily in SH-SY5Y neuroblastoma cells and primary cultures of postnatal astrocytes (Fig. 2). Low levels of caspase-3 protein were detected occasionally in cultures of embryonic telencephalic neurons by Western blot analysis, but this was not observed consistently (data not shown). Despite the relative absence of caspase-3 immunoreactivity, the presence of DEVD cleaving activity in extracts derived from murine neuronal cultures is consistent with observations that the DEVD substrate can be cleaved by caspase- 2 and caspase-7 in addition to caspase-3 (Garcia-Calvo et al., 1998). The finding that distinct caspase family members are expressed differentially within neurons and glia in culture suggested that these proteins may serve unique functions in these cell types.

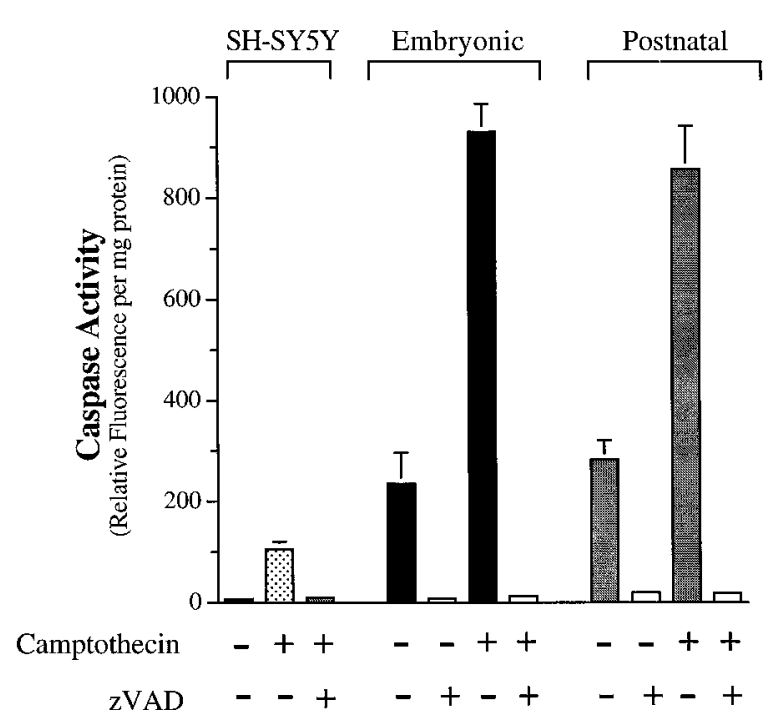

Figure 1. Camptothecin-induced DNA damage activates caspase activity in human SH-SY5Y neuroblastoma cells and in $\mathrm{p} 53^{+/+}$embryonic telencephalic and postnatal cortical neurons. SH-SY5Y cells and embryonic and postnatal neurons were plated as described in Materials and Methods. After $2 \mathrm{~d}$ (SH-SY5Y cells) or $4 \mathrm{~d}$ (primary neurons) in culture, the cells were treated with DMSO (control) or camptothecin $(0.5 \mu \mathrm{M}$ for SH-SY5Y cells and $1 \mu \mathrm{M}$ for primary neurons) in the presence or absence of a cell-permeable irreversible tripeptide caspase antagonist (zVAD-fmk; 20 $\mu \mathrm{M})$. The cells were harvested after $24 \mathrm{hr}$, and cytosolic extracts were prepared and evaluated for zDEVD-AFC cleavage activity, as described in Materials and Methods. The extracts were incubated with a fluorogenic substrate, zDEVD-AFC (100 $\mu \mathrm{M}$ final concentration; Enzyme Systems Products) at $37^{\circ} \mathrm{C}$. The extent of substrate hydrolysis was determined after a $45 \mathrm{~min}$ incubation period (hydrolysis is linear for up to $60 \mathrm{~min}$ ) and is expressed as arbitrary fluorescence units per milligram of protein. The results represent the mean $\pm \mathrm{SD}(n=3$ cultures per condition) and are representative of four separate experiments. Caspase activity in camptothecin-treated cultures differed significantly from control cultures and from all cultures treated with zVAD-fmk ( $p<0.001$, ANOVA). Some data points do not express SE bars because they are small enough to be contained within the symbols.
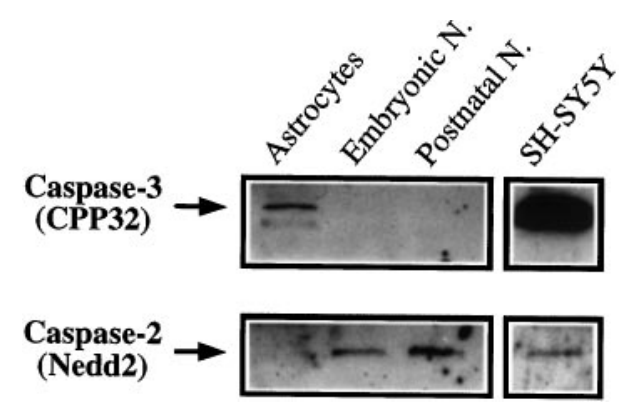

Figure 2. Differential expression of caspase-2 (Nedd2) and caspase-3 (CPP32) in cultured neurons and astrocytes. Embryonic telencephalic neurons $\left(\mathrm{p} 53^{+/+}, \mathrm{E} 14.5\right)$, postnatal cortical neurons (p53 $\left.3^{+/+}, \mathrm{P} 0\right)$, postnatal astrocytes $\left(\mathrm{p} 53^{+/+}, \mathrm{P} 0\right)$, and SH-SY5Y cells were plated as described in Materials and Methods. Cellular extracts were prepared from all cell types after $4 \mathrm{~d}$ in culture in the absence of injury. Protein samples $(50 \mu \mathrm{g}$ of protein per lane) were resolved by SDS-PAGE, and immunoblotting was performed with a caspase-2 (Nedd2) or caspase-3 (CPP32) antibody, as described in Materials and Methods. Separate gels were used for each antibody. The results are representative of three separate experiments. 
A) Embryonic Neurons

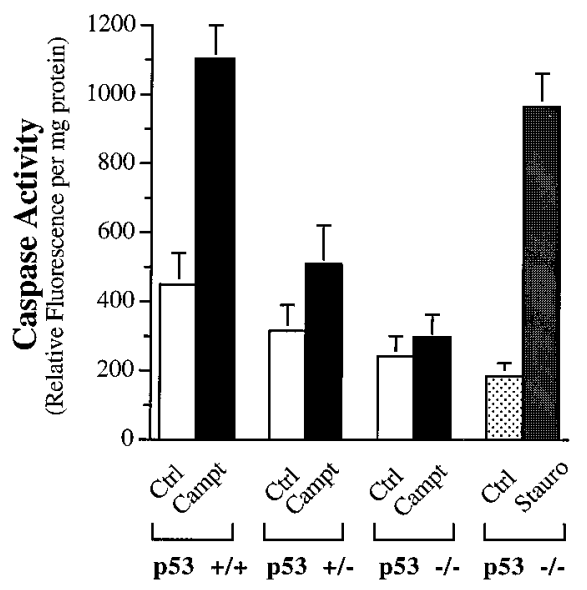

B) Postnatal Neurons

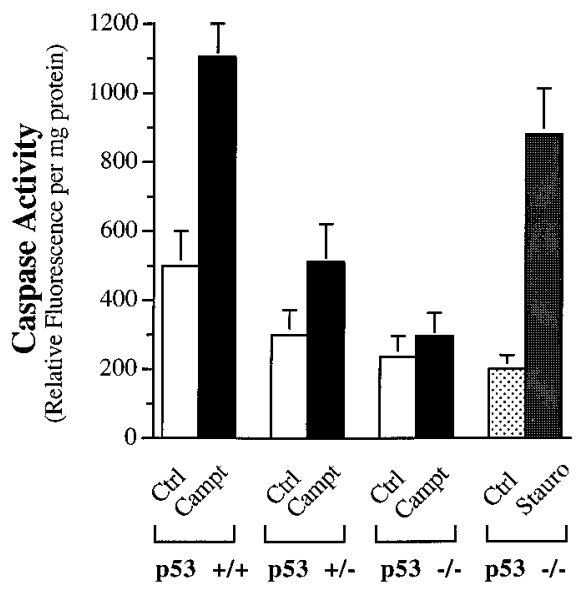

Figure 3. DNA damage induces caspase activity in cultured embryonic telencephalic and postnatal cortical neurons in a p53-dependent manner. Primary cultures of embryonic or postnatal neurons were established from wildtype mice $\left(\mathrm{p} 53^{+/+}\right)$or mice deficient in one $\left(\mathrm{p} 53^{+/-}\right)$or both $\left(\mathrm{p} 53^{-/-}\right)$p53 alleles, as described in Materials and Methods. After $4 \mathrm{~d}$ in culture the neurons were treated with DMSO (control, Ctrl), camptothecin (Campt; $1 \mu \mathrm{M})$, or staurosporine (Stauro; $0.5 \mu \mathrm{M}, \mathrm{p} 53^{-/-}$ only). The cells were harvested after 24 $\mathrm{hr}$, and cytosolic extracts were prepared and evaluated for zDEVD-AFC cleavage activity as described in Materials and Methods. The results represent the mean $\pm \mathrm{SD}(n=3$ cultures per condition) and are representative of three separate experiments. Caspase activity in camptothecin-treated cultures dif-

fered significantly from caspase activity in control cultures for $\mathrm{p} 53^{+/+}\left(p<0.001\right.$, ANOVA) and $\mathrm{p} 53^{+/-}(p<0.01$, ANOVA) genotypes. Caspase activity in staurosporine-treated $\mathrm{p} 53^{-1-}$ cultures differed significantly from control cultures $(p<0.001$, ANOVA). Basal levels of caspase activity only differed significantly between $53^{+/+}$and $553^{-/-}$cultures (embryonic and postnatal cultures; $p<0.05$, ANOVA).

To determine whether the caspase activation observed in neuronal cells after DNA damage required the presence of p53, we exposed embryonic telencephalic and postnatal cortical neurons derived from p53 wild-type $(+/+)$, p53-heterozygous $(+/-)$, and p53-deficient $(-/-)$ mice to camptothecin $(1 \mu \mathrm{M})$, and we subsequently assayed them for caspase activation with the fluorogenic assay. Basal levels of caspase activity were detected in vehicle-

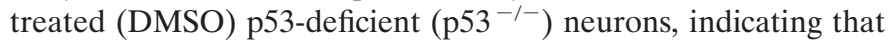
these proteases were expressed constitutively in the absence of p53 (Fig. 3). However, basal levels of caspase activity were higher in neurons containing one or both p53 alleles (p53 $\left.3^{+/-}, \mathrm{p} 53^{+/+}\right)$, consistent with our previous demonstration that the percentage of p53 wild-type and p53 heterozygous neurons surviving in basal growth conditions was significantly lower than that of $\mathrm{p} 53^{-/-}$ neurons (H. Xiang et al., 1996).

Although p53 was not required for constitutive expression of basal levels of caspase activity, deletion of the p53 gene completely abrogated the increase in caspase activity induced by DNA damage (Fig. 3). Caspase induction was dependent on gene copy number, because $\mathrm{p} 53^{+/-}$neurons displayed a degree of caspase activation after DNA damage that was intermediate between that observed in $\mathrm{p} 53^{+/+}$and $\mathrm{p} 53^{-/-}$neurons. This requirement for $\mathrm{p} 53$ was observed in both embryonic and postnatal neurons.

Staurosporine is a protein kinase inhibitor that induces programmed cell death in a wide variety of cell types, including neurons (Jacobson et al., 1996; Wiesner and Dawson, 1996; Prehn et al., 1997). Staurosporine $(0.5 \mu \mathrm{M})$ induced significant neurite fragmentation and degeneration as well as nuclear condensation and cell loss in $\mathrm{p} 53^{-1-}$ embryonic and postnatal neurons (data not shown), as previously described (Johnson et al., 1998). In contrast to camptothecin, however, staurosporine significantly increased caspase activity in p53 $3^{-1-}$ neurons (Fig. 3 ). These data demonstrated that caspases are present and competent to undergo activation in p53-deficient neurons in response to an appropriate stimulus. Thus, caspase activation induced by DNA damage in neurons required the presence of a functional p53 gene.

\section{Caspase-mediated cell death is dependent on the state of neuronal maturation}

To determine whether p53-dependent caspase activation was necessary for neuronal cell death after DNA damage, we examined the ability of specific caspase inhibitors to promote neuronal survival after camptothecin exposure either by directly counting viable neurons or by using a live/dead cell assay. Concurrent treatment of SH-SY5Y neuroblastoma cells with zVAD-fmk (100 $\mu \mathrm{M})$ significantly protected the cells from camptothecin-induced cell death (Fig. 4). Some degree of protection from cell death was evident as long as $72 \mathrm{hr}$ after camptothecin exposure, whereas nearly all cells had died within $24 \mathrm{hr}$ in the absence of zVAD-fmk. The protection afforded by zVAD-fmk was not complete, however, in that cell death gradually increased in the cultures over time (data not shown). Consistent with the results obtained with SH-SY5Y cells, caspase inhibitors also protected embryonic telencephalic neurons from camptothecin-induced cell death. Whereas 45 and $25 \%$ of cultured embryonic neurons remained at $24 \mathrm{hr}$ after camptothecin treatment in the presence of zVAD-fmk $(100 \mu \mathrm{M})$ and zDEVD-fmk $(100 \mu \mathrm{M})$, respectively, $<5 \%$ of embryonic neurons survived in the absence of caspase inhibitors (Fig. 5A). The increased survival that was noted between zVADfmk-treated and zDEVD-fmk-treated cultures $(p<0.01)$ may reflect the broader specificity of zVAD-fmk for caspases. As observed with SH-SY5Y cells, however, caspase inhibitors only delayed cell death in cultured embryonic neurons. There was not a significant difference in survival at $48 \mathrm{hr}$ between embryonic neurons treated with camptothecin $(1 \mu \mathrm{M})$ and those treated with camptothecin and zVAD-fmk (100 $\mu \mathrm{M}$; mean percentage of survival $\pm \mathrm{SD}$ at $48 \mathrm{hr}$ was $3.72 \pm 0.44$ and $3.64 \pm 0.38$, respectively; $p>0.54 ; n=6$ ). Moreover, multiple additions of zVAD-fmk or zDEVD-fmk at the time of camptothecin treatment and $24 \mathrm{hr}$ after treatment also failed to enhance the long-term survival of embryonic telencephalic neurons (data not shown).

In contrast to the protective effects of caspase inhibition seen at $24 \mathrm{hr}$ after DNA damage in cultured SH-SY5Y neuroblastoma cells and embryonic telencephalic neurons, no such protection was observed in cultured postnatal cortical neurons. Although zVAD-fmk $(100 \mu \mathrm{M})$ completely prevented the increase in 

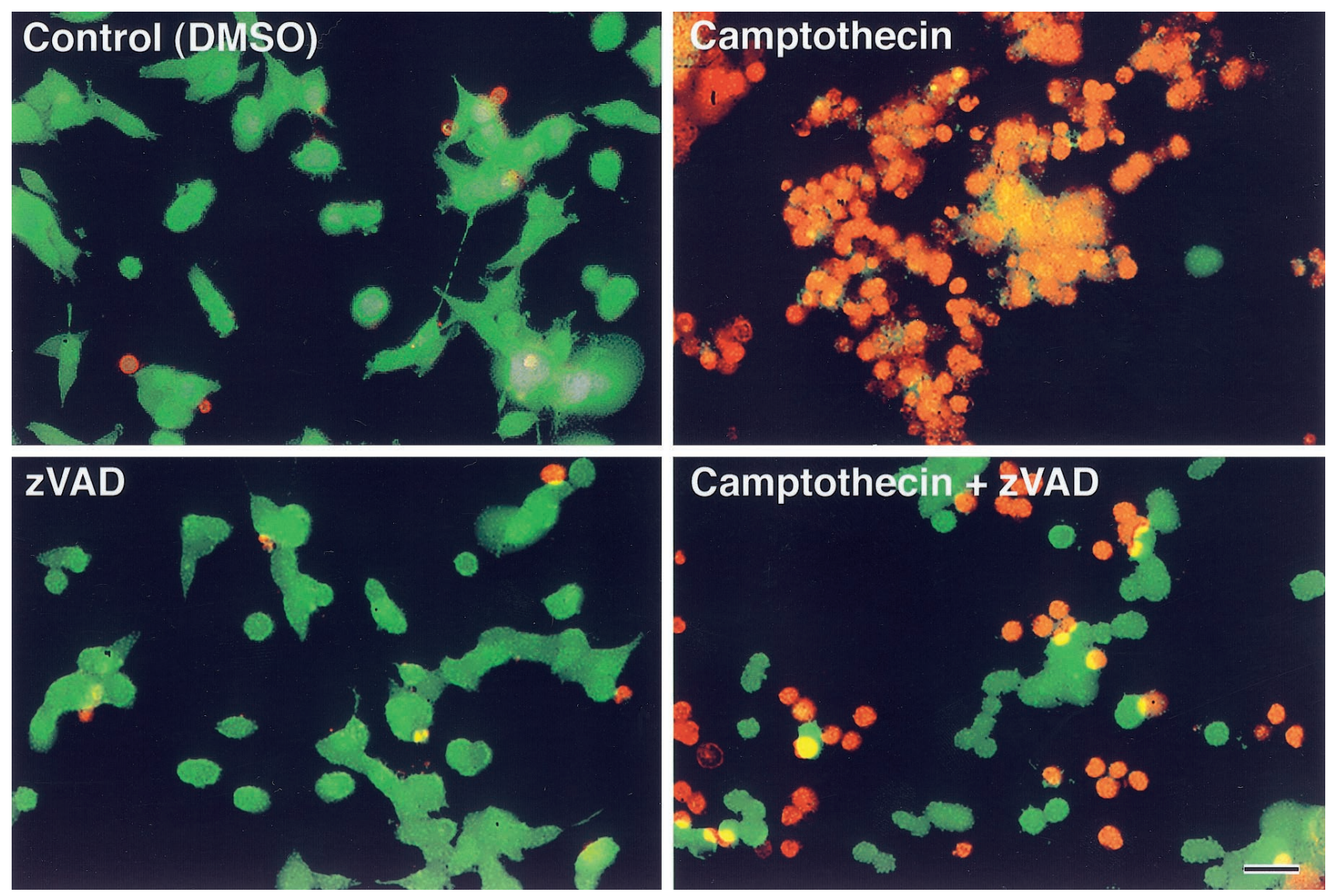

Figure 4. Camptothecin-induced cell death in human SH-SY5Y neuroblastoma cells is inhibited by zVAD-fmk. SH-SY5Y human neuroblastoma cells were plated and maintained in basal culture conditions for $3 \mathrm{~d}$, as described in Materials and Methods. Cells subsequently were maintained in medium plus DMSO (Control) or medium plus zVAD-fmk $(z-V A D ; 100 \mu \mathrm{M})$ or were treated with a single dose of camptothecin $(0.5 \mu \mathrm{M})$ or camptothecin plus zVAD-fmk $(100 \mu \mathrm{M})$. At $1 \mathrm{~d}$ after treatment, calcein-AM and ethidium homodimer-1 were added to the culture medium, and the cells were processed and analyzed as described in Materials and Methods. Cells were viewed with fluorescein and rhodamine optics and represented as a double exposure. Calcein-positive cells ( green fluorescence) indicate healthy cells with an intact plasma membrane, whereas ethidium homodimer-1-positive cells (orange fluorescence) represent dead or severely damaged cells. The addition of zVAD-fmk by itself had no effect on cell viability, whereas zVAD-fmk protected SH-SY5Y cells from camptothecin-induced cell death. The results are representative of three separate experiments. Scale bar, $20 \mu \mathrm{m}$.

caspase activity induced by camptothecin in postnatal cortical neurons (see Fig. 1), it failed to protect these neurons from cell death (Fig. $5 A$ ). Other caspase inhibitors such as zDEVD-fmk (20-100 $\mu \mathrm{M})$ (Fig. 5A), BAF $(20 \mu \mathrm{M})$, and zVDVAD-fmk (20$100 \mu \mathrm{M})$ (data not shown) also failed to promote the survival of postnatal cultured cortical neurons after DNA damage, although they also suppressed the increase in caspase-like cleavage activity (evaluated for zDEVD-fmk and zVDVAD-fmk; data not shown). Caspase inhibitors also failed to protect postnatal cortical neurons from cell death induced by $\gamma$-irradiation (10-30 Gy; Johnson et al., 1998) and the nitric oxide donor, sodium nitroprusside (0.2-1.0 mM) (our unpublished observations).

The relationship between caspases and neuronal cell death was evaluated further in embryonic and postnatal neurons, using annexin $\mathrm{V}$ binding as an additional measure of cell viability (Fig. $6)$. One of the early events in programmed cell death is the externalization of phosphatidylserine, a membrane phospholipid normally restricted to the inner leaflet of the plasma membrane. Annexin $\mathrm{V}$, an endogenous human protein with a high affinity for membrane-bound phosphatidylserine, has been used in vitro to detect apoptosis before other well described morphological or nuclear changes associated with programmed cell death become evident. Camptothecin increased annexin $\mathrm{V}$ binding in both embryonic telencephalic (Fig. 6A) and postnatal cortical neurons (Fig. $6 B$ ). The addition of the broad spectrum caspase inhibitor, zVAD-fmk $(20 \mu \mathrm{M})$, significantly reduced annexin $\mathrm{V}$ binding to embryonic telencephalic neurons $8 \mathrm{hr}$ after camptothecin treatment. In marked contrast, zVAD-fmk $(20 \mu \mathrm{M})$ had no effect on annexin $\mathrm{V}$ binding to postnatal cortical neurons $8 \mathrm{hr}$ after camptothecin treatment. These results demonstrate that a caspasemediated process regulates the loss of viability in camptothecintreated embryonic, but not postnatal, neurons. Moreover, these findings suggest the presence of a p53-dependent, caspaseindependent cell death pathway in postnatal primary cortical neurons that is initiated in parallel with caspase activation. Taken together with the results obtained by using SH-SY5Y cells and embryonic neurons, these data indicate that the contribution of caspases to neuronal cell death may vary, depending on the stage of neuronal maturation.

\section{Excitotoxicity was not associated with caspase activation}

We considered the possibility that p53 might induce neuronal cell death under some circumstances without activating caspases. Such a result would provide additional evidence for a p53dependent, caspase-independent cell death pathway. Previously, 
A) Caspase Inhibitors

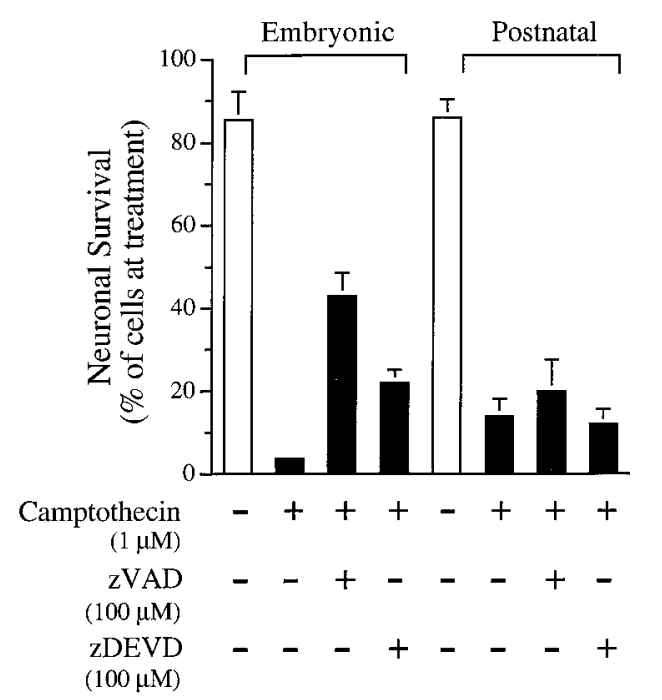

B) PARP Inhibitor

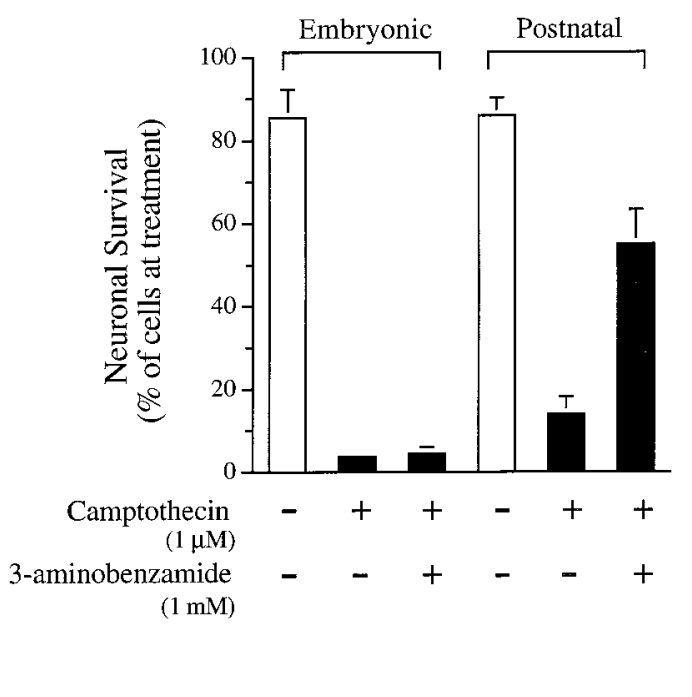

Figure 5. Caspase and PARP inhibitors differentially suppress camptothecin-induced cell death in $\mathrm{p}^{+} 3^{+/+}$embryonic and postnatal neurons. Embryonic telencephalic and postnatal cortical neurons were plated and maintained in basal culture conditions for $4 \mathrm{~d}$, as described in Materials and Methods. Cells were treated with DMSO (control) or with a single dose of camptothecin $(1 \mu \mathrm{M})$ in the presence or absence of $(A)$ the caspase inhibitors zVAD-fmk $(100$ $\mu \mathrm{M})$ or zDEVD-fmk $(100 \mu \mathrm{M})$ or $(B)$ a PARP inhibitor (3-aminobenzamide, $1 \mathrm{mM})$. Neuronal survival was assessed $24 \mathrm{hr}$ later by counting the number of viable neurons (H. Xiang et al., 1996). All data are the mean \pm SD of 12 cultures from three separate experiments. Neuronal survival in cultures treated with camptothecin plus zVAD-fmk or camptothecin plus zDEVD-fmk differed significantly from survival in cultures treated with camptothecin alone for embryonic neurons only $(p<0.001$, ANOVA). Neuronal survival in cultures treated with camptothecin plus 3-aminobenzamide differed significantly from survival in cultures treated with camptothecin for postnatal neurons only $(p<0.001$, ANOVA).

it was shown that glutamate exposure upregulated Bax protein levels in postnatal cortical neurons in a p53-dependent manner (Xiang et al., 1998), and glutamate-mediated excitotoxicity in cortical neurons was inhibited by deletion of the $\mathrm{p} 53$ gene in vivo and in vitro (Morrison et al., 1996; H. Xiang et al., 1996). In contrast to glutamate, camptothecin did not increase Bax protein levels significantly, indicating that glutamate and camptothecin were capable of activating distinct p53-dependent signal transduction pathways. We therefore examined whether glutamatemediated excitotoxicity also was associated with caspase activation. As previously described, glutamate treatment (100 $\mu \mathrm{M})$ resulted in the death of $50 \%$ of cultured cortical neurons over a period of several days. In contrast to camptothecin, however, glutamate exposure did not cause an increase in caspase cleavage activity in cultured postnatal cortical neurons (Fig. 7A). To insure that the lack of caspase activation observed with $100 \mu \mathrm{M}$ glutamate was not attributable to necrosis, we also examined the effect of lower glutamate concentrations $(1-10 \mu \mathrm{M})$ on caspase activity. These concentrations of glutamate did not produce an increase in caspase activity, although $10 \mu \mathrm{M}$ glutamate was associated with significant neuronal damage (data not shown). Consistent with this result, concurrent treatment of cultured postnatal cortical neurons with caspase inhibitors (zVAD-fmk, $100 \mu \mathrm{M}$; zDEVDfmk, $100 \mu \mathrm{M}$ ) failed to promote the survival of these cells after glutamate exposure (Fig. 7B). However, glutamate-mediated excitotoxicity was attenuated significantly by p53 deletion as previously described (H. Xiang et al., 1996) or by concurrent treatment with the poly(ADP-ribose) polymerase (PARP) inhibitor, 3-aminobenzamide (see below), demonstrating that neuronal toxicity could be mitigated when the appropriate cell death pathways were targeted. This result suggests that, under the culture conditions used in the present study, glutamate-mediated cell death occurred in a p53-dependent, caspase-independent manner, although we cannot rule out the contribution of caspases that are insensitive to zVAD-fmk and unable to cleave the DEVD substrate.

\section{Adenovirus-mediated overexpression of p53 promotes neuronal cell death but does not induce caspase activity}

To establish further that p53 could mediate neuronal cell death independently of caspase activation, we overexpressed p53 in primary cortical neurons by using adenovirus-mediated gene transfer. We and others have reported previously that adenovirusmediated overexpression of p53 leads to neuronal cell death (Slack et al., 1996; H. Xiang et al., 1996; Jordan et al., 1997b). As reported previously (H. Xiang et al., 1996), p53 overexpression in cultured postnatal cortical neurons resulted in neurite fragmentation, nuclear condensation, and neuronal cell death over a 48-72 hr period. When specific caspase activity was measured, there was an increase in caspase cleavage activity that was associated with the process of adenovirus infection relative to noninfected cells (data not shown). This increase, however, was not associated with cell death, as demonstrated by the stable survival of cultures transduced with the lacZ control virus (H. Xiang et al., 1996). There was no significant difference in caspase cleavage activity between $\mathrm{p} 53^{+/+}$or $\mathrm{p} 53^{-/-}$primary cortical neurons overexpressing p53 and control cells overexpressing $\beta$-galactosidase (Fig. 8). Consistent with these findings, we did not observe any reduction in the number of ethidium homodimer-1-stained $\mathrm{SH}$ SY5Y cells when treated concomitantly with the p53 adenovirus and zVAD-fmk (100 $\mu \mathrm{M}$; data not shown). These findings demonstrate that p53 can promote neuronal cell death independently of caspase activity. 


\section{(A) Embryonic Neurons}
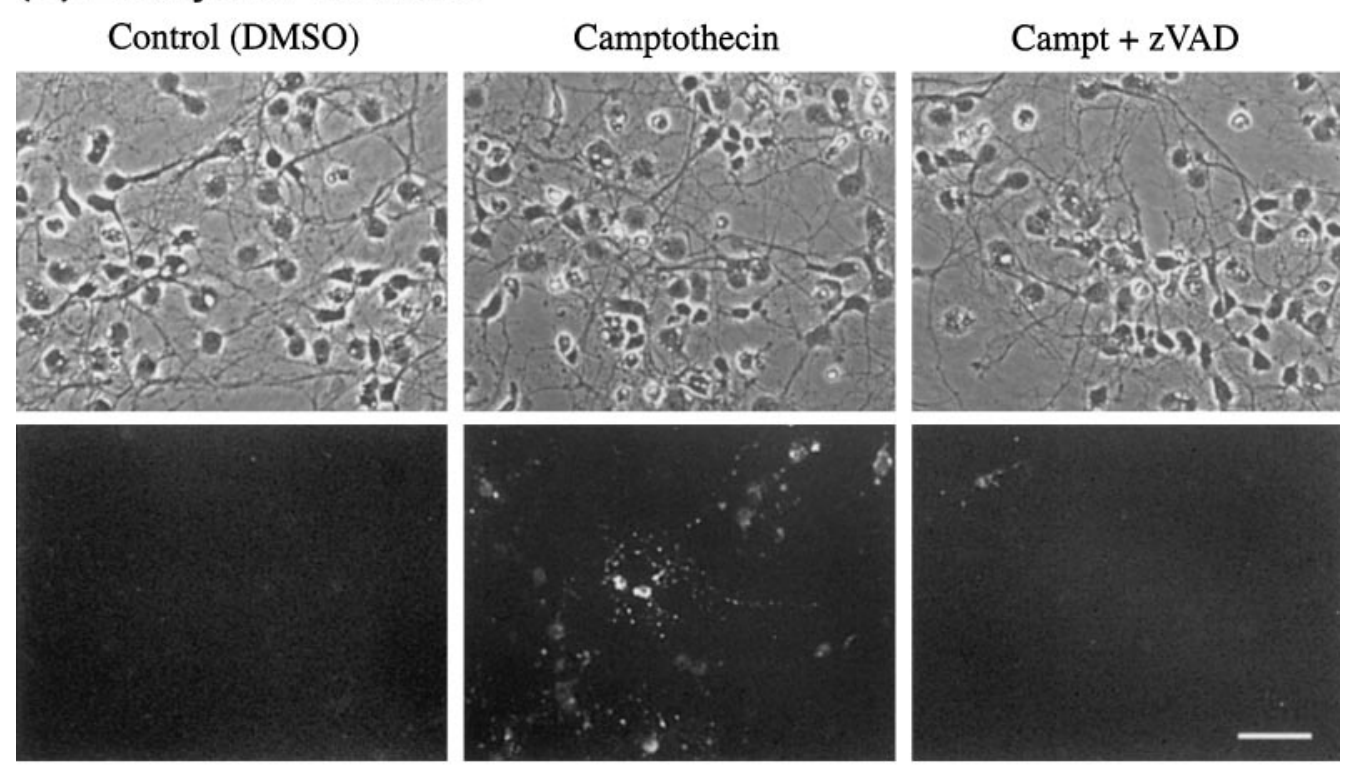

Figure 6. Annexin V staining after DNA damage is suppressed selectively by a caspase inhibitor in embryonic, but not postnatal, neurons. Embryonic telencephalic $(A)$ and postnatal cortical $(B)$ neurons $\left(\mathrm{p} 53^{+/+}\right)$were plated and maintained in basal culture conditions for $4 \mathrm{~d}$, as described in Materials and Methods. Cells were treated with DMSO (Control), camptothecin (1 $\mu \mathrm{M})$, or camptothecin plus zVADfmk $($ Campt $+z V A D ; 20 \mu \mathrm{M})$. At 8 $\mathrm{hr}$ after treatment the cells were stained with Annexin V-FITC, as described in Materials and Methods. Cells were viewed with phasecontrast optics (top rows) or viewed with fluorescein optics (bottom rows). Relative to DMSO-treated cells, the number of annexin $\mathrm{V}$-stained cells was increased significantly by camptothecin treatment in both embryonic $(A)$ and postnatal $(B)$ neuronal cultures. Whereas the number of annexin V-stained cells was reduced dramatically by concurrent treatment with zVAD-fmk in embryonic cultures $(A)$, the caspase inhibitor had no effect on the number of annexin V-labeled cells in postnatal neuronal cultures $(B)$. The results are representative of two separate experiments, each performed with newly established primary cultures. Scale bars, $40 \mu \mathrm{m}$.

\section{(B) Postnatal Neurons}

Control (DMSO)
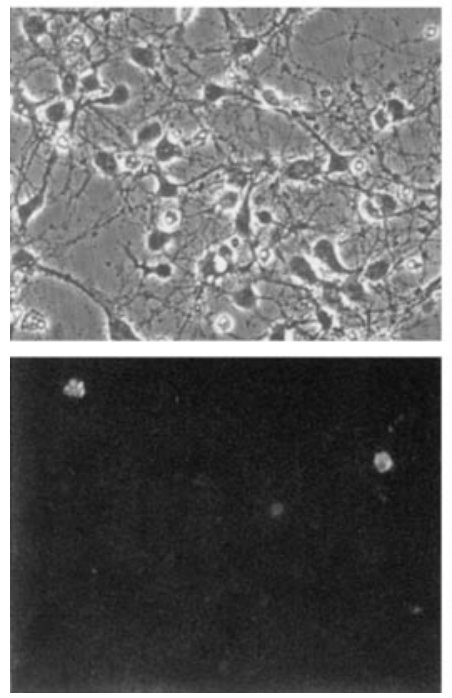

Camptothecin
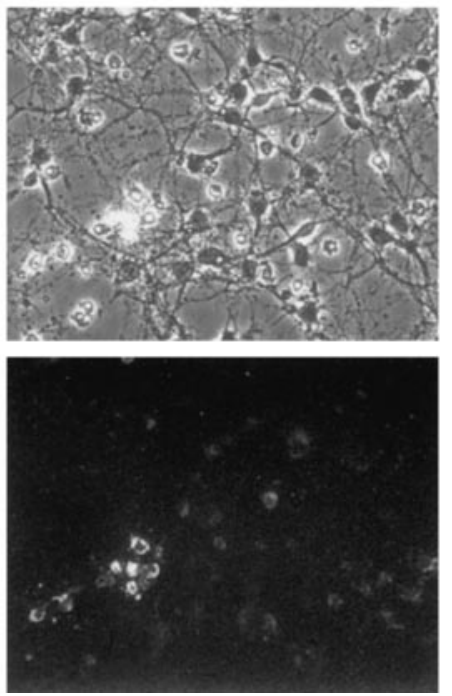

Campt + zVAD
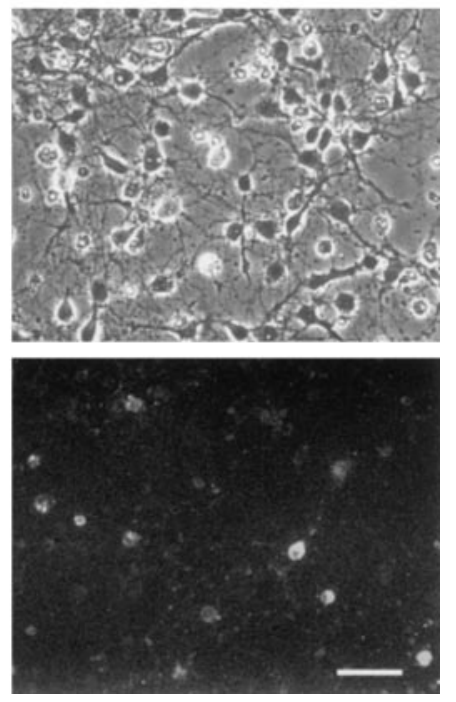

\section{Sensitivity to a PARP-dependent cell death pathway is dependent on the state of neuronal maturation}

PARP is a DNA repair enzyme that is activated by DNA damage and specifically cleaved by caspases (Nicholson and Thornberry, 1997). Because PARP also has been implicated in the regulation of p53-mediated transcriptional activity (Whitacre et al., 1995; Vaziri et al., 1997) and neuronal damage after injury (Eliasson et al., 1997; Endres et al., 1997; Takahashi et al., 1997), we investigated the role of PARP activity in p53-mediated neuronal cell death. The addition of the PARP inhibitor, 3-aminobenzamide (3-AB, $1 \mathrm{~mm}$ ), protected cultured postnatal cortical neurons from cell death induced by DNA damage (see Fig. $5 B$ ) or glutamate exposure (see Fig. 7B). However, PARP inhibition did not suppress the induction of caspase activity in these cells after DNA damage (data not shown), suggesting that the protection conferred by PARP inhibition occurred independently, or down- stream, of p53 activation and caspase activation in postnatal neurons.

Given the inability of the PARP inhibitor to suppress caspase activation after DNA damage, we reasoned that the effect of PARP inhibition would be minimized in embryonic telencephalic neurons, where caspase activity played a prominent role in cell death (as indicated by the ability of caspase inhibitors to suppress cell death). As predicted, embryonic telencephalic neurons exposed to camptothecin were not protected from cell death by the PARP inhibitor 3-AB (see Fig. 5B). Assays of caspase cleavage activity demonstrated that $3-\mathrm{AB}$ had no effect on the induction of caspase activity by DNA damage in embryonic telencephalic neurons (data not shown). These results suggested that PARP contributes to injury-induced cell death in postnatal, but not embryonic, cortical neurons and provided further support for developmental regulation of injury-induced cell death pathways in neurons. 
A) Caspase Activity

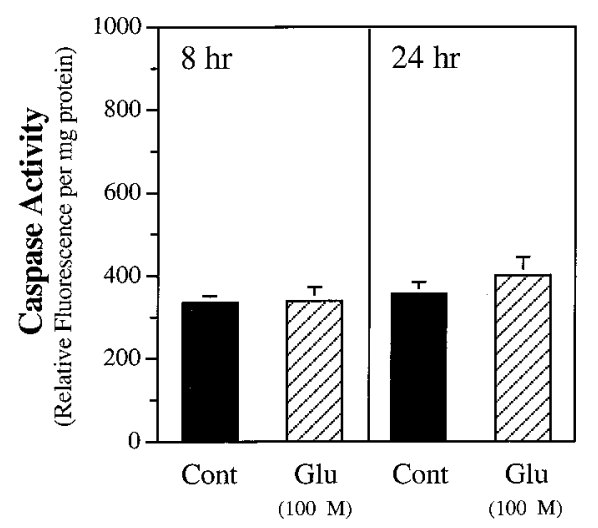

B) Neuronal Survival

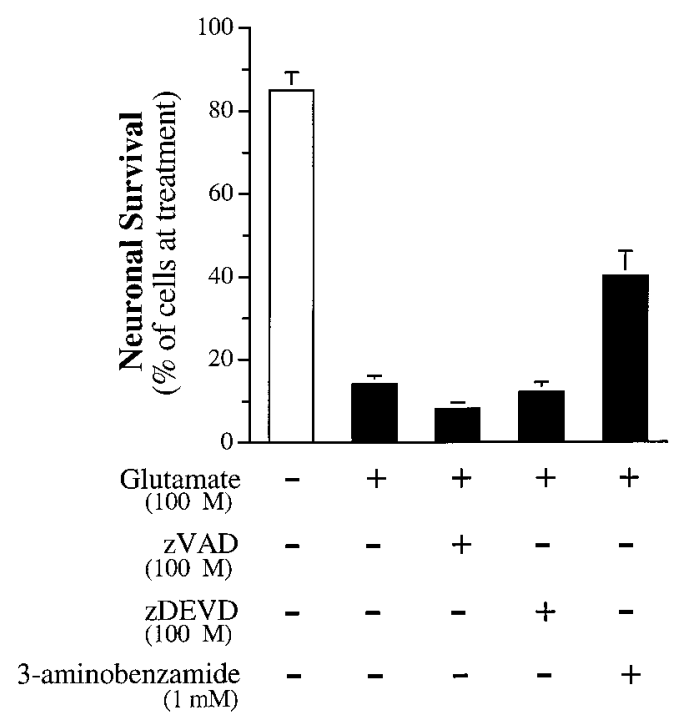

Figure 7. A, Glutamate treatment did not stimulate caspase activity in p53 $3^{+/+}$ postnatal cortical neurons. Postnatal cortical neurons were plated and maintained in basal culture conditions for $4 \mathrm{~d}$, as described in Materials and Methods. Cells were treated either with saline (control, Cont) or with a single dose of glutamate (Glu; $100 \mu \mathrm{M})$. Caspase activity was evaluated 8 and 24 $\mathrm{hr}$ after treatment by monitoring zDEVD-AFC cleavage activity, as described in Materials and Methods. The results represent the mean $\pm \mathrm{SD}(n=9$ cultures per condition) and were derived from three separate experiments. Caspase activity in glutamate-treated cultures did not differ significantly from control cultures ( $p>0.35$, ANOVA). $B$, Glutamate-mediated excitotoxicity was suppressed by a PARP inhibitor, but not by the addition of caspase inhibitors. Cells were treated with saline (control) or with a single dose of glutamate $(100 \mu \mathrm{M})$ in the presence or absence of the caspase inhibitors, zVAD-

fmk $(100 \mu \mathrm{M})$ or zDEVD-fmk (100 $\mu \mathrm{M})$, or a PARP inhibitor, 3-aminobenzamide (1 mM). Neuronal survival was assessed 24 hr later by counting the number of viable neurons. All data are the mean \pm SD of nine cultures from three separate experiments. Neuronal survival in cultures treated with glutamate plus 3-aminobenzamide differed significantly from survival in cultures treated with glutamate alone ( $p<0.01$, ANOVA).

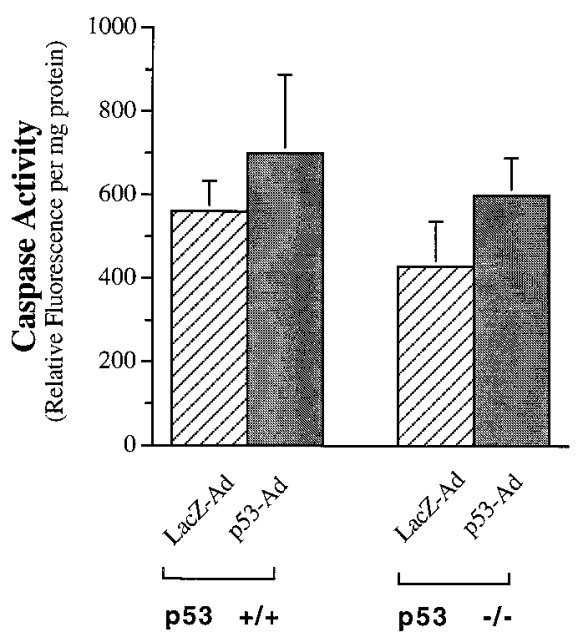

Figure 8. p53-induced neuronal cell death can occur independently of caspase activation. Postnatal cortical neurons ( $553^{+/+}$and ${\mathrm{p} 53^{-/-}}^{-}$were plated and maintained in basal culture conditions, as described in Materials and Methods. At $4 \mathrm{~d}$ after plating the cells were infected with adenovirus expressing either the $\beta$-galactosidase gene ( $L a c Z$ - $A d$; multiplicity of infection $=250)$ or the human wild-type p53 gene $(p 53-A d$; multiplicity of infection $=250$ ). Caspase activity was evaluated $48 \mathrm{hr}$ after infection by monitoring zDEVD-AFC cleavage activity as described in Materials and Methods. The results represent the mean \pm SD $(n=9$ cultures per condition) and were derived from three separate experiments. Caspase activity did not differ significantly between LacZ-Adinfected control cultures and p53-Ad-infected cultures $\left(p>0.34, \mathrm{p} 53^{+/+}\right.$ neurons; $p>0.28, \mathrm{p} 53^{-1-}$ neurons; ANOVA).

\section{DISCUSSION}

The tumor suppressor gene p53 has been implicated in the loss of neuronal viability, but the signaling events associated with p53mediated cell death are not understood. In the present study we determined if p53-mediated neuronal cell death required caspase activation. The results of this study demonstrate (1) that caspase activation is regulated by both p53-dependent and p53- independent pathways, depending on the nature of the injury stimulus; (2) that the inhibition of caspase activity does not necessarily prevent neuronal cell death after injury; and (3) that the relative importance of caspase-dependent pathways during neuronal cell death depends on both the developmental status of the cell type examined and the specific nature of the death stimulus.

\section{Caspase activation is dependent on p53 expression}

Our results clearly indicated that caspase activation seen in response to DNA damage was dependent on the presence of a functional p53 gene. Although the molecular linkage between p53 activity and caspase activation in neurons has not been defined, recent studies that used other cell types also have demonstrated that p53 is required for caspase activation. For example, caspasemediated $\mathrm{Rb}$ cleavage after IL-3 withdrawal in lymphoid cells only occurred in the presence of functional p53 (Gottlieb and Oren, 1998). Also, p53 enhanced the susceptibility to caspasemediated cell death by upregulating expression of the Fas/Fas ligand system (Owen-Schaub et al., 1995; Bennett et al., 1998), which has been implicated in cell death occurring in neurodegenerative conditions (de la Monte et al., 1998; Sakurai et al., 1998; Shin et al., 1998). p53-mediated caspase activation may occur via direct protein-protein interactions (Ding et al., 1998) as opposed to transcriptional activation by $\mathrm{p} 53$.

\section{Caspase inhibition delays cell death in embryonic neurons, but not postnatal neurons}

Caspases are common cell death effectors in many cell types (Cohen, 1997; Nicholson and Thornberry, 1997), including cells derived from the peripheral nervous system (Deshmukh et al., 1996; Vekrellis et al., 1997) and the CNS (Kuida et al., 1996, 1998; Keane et al., 1997; Hakem et al., 1998). Caspases have been implicated in neuronal cell death during embryonic development (Milligan et al., 1995; Kuida et al., 1996, 1998; Keane et al., 1997; Hakem et al., 1998) and in response to a multitude of cytotoxic insults, including excitotoxicity (Nath et al., 1996; Du et al., 1997; Jordan et al., 1997a; Tenneti et al., 1998), oxygen-glucose depri- 
vation (Loddick et al., 1996; Friedlander et al., 1997b; Gottron et al., 1997; Hara et al., 1997a,b; Cheng et al., 1998; Himi et al., 1998; Namura et al., 1998; Schielke et al., 1998), trophic factor deprivation (Rabizadeh et al., 1993; Gagliardini et al., 1994; Martinou et al., 1995; Deshmukh et al., 1996; Troy et al., 1997), traumatic brain injury (Yakovlev et al., 1997), and chronic degenerative insults (Goldberg et al., 1996; Friedlander et al., 1997a; Wellington et al., 1998). Results obtained in the present study using embryonic neurons are consistent with these reports. In marked contrast to these reports, however, is the present observation that broad-spectrum caspase inhibitors had no effect on the survival of injured postnatal neurons in culture. One interpretation of these results is that caspase activation is not associated exclusively with cell death in neurons.

It is conceivable that other, novel caspases that are not inhibited by the spectrum of substrate antagonists used in the present study and that are not detected by the caspase activity assay used are, nevertheless, involved in mediating injury-induced cell death in postnatal cortical neurons. Recent studies have provided clear evidence for the presence of caspase-1 (Bhat et al., 1996), caspase-2 (Kumar et al., 1994), caspase-3 (Kuida et al., 1996; Krajewska et al., 1997; Ni et al., 1997), and caspase-9 (Hakem et al., 1998; Kuida et al., 1998) in the brain. Caspase-1 immunoreactivity has been localized to microglial cells in the brain after ischemic injury and was not detected in neurons (Bhat et al., 1996). Recently, caspase-3 immunoreactivity has been observed in neurons after transient focal ischemia (Namura et al., 1998). Immunoreactivity corresponding to full-length caspase-3 (p32) was expressed constitutively in neurons throughout normal brain, whereas immunoreactivity corresponding to activated caspase-3 (p20) was prominent in neuronal cell bodies after reperfusion injury. However, these results contrast with the findings of Krajewska et al. (1997), who found little or no caspase-3 (CPP32) immunoreactivity in normal human adult brain and spinal cord neurons. Interestingly, in the latter study, moderate levels of caspase-3 immunoreactivity were detected in astrocytes, consistent with the results from the present study (see Fig. 2), which used cultured astrocytes. One may speculate that caspases derived from non-neuronal cells may contribute to the initiation and progression of neuronal damage after injury. Moreover, it is conceivable that caspase activation in neurons, as seen after cerebral ischemia (Namura et al., 1998), only occurs in response to specific cytotoxic insults and is dependent on neuronal-glial interactions.

The contribution of non-neuronal caspases to neuronal cell death during embryonic development or after injury has not been addressed critically. A careful assessment of the many recent reports involving caspases in cell death that used models of cultured neurons suggested two common features that may explain the disparity observed in the present study with respect to the role of caspases in postnatal neurons: (1) the majority of these studies used embryonic neuronal cultures or cerebellar granule neurons, both of which represent models of developing neurons; (2) many of these studies involved the use of mixed neuronal-glial cultures. The activation of caspases in non-neuronal cells conceivably could contribute to neuronal damage after injury by promoting the processing of cytokines and other inflammatory mediators (Kuida et al., 1995) or by direct action on neurons after release from damaged cells. Thus, the reduction in damage seen in transgenic mice with genetically reduced levels of caspase activity or after the intracerebral injection of caspase inhibitors after injury could be attributable to a suppressed inflammatory reaction (Friedlander et al., 1997b; Hara et al., 1997a) and not to the interruption of a cell autonomous apoptotic pathway in neurons. This is consistent with the finding that, after focal ischemia, the brains of caspase-1-deficient mice contained decreased levels of the immune modulator, interleukin- $1 \beta$, which is processed by caspase-1 (Hara et al., 1997a). Therefore, it is difficult to rule out effects of the caspase inhibitors on non-neuronal cells. The results of the present study, involving several distinct forms of injury to highly purified neuronal cultures, suggest that caspase activation is coupled directly to cell death in embryonic, but not postnatal, neurons.

One possible explanation for the current findings is that the cellular mechanisms underlying neuronal cell death after cytotoxic injury differ from those underlying developmentally programmed cell death. The activation of caspases during neuronal development appears to be essential for regulating the number of neurons surviving in the postdevelopmental brain. Because caspase activation often results in nuclear and cytoplasmic condensation (Janicke et al., 1998), these proteases may be essential for the rapid packaging and elimination of dying cells during the precisely orchestrated period of neuronal development. The failure to eliminate dying cells efficiently during development could impair the orderly migration and differentiation of neurons, leading to severe disturbances in telencephalic development, as recently have been reported for mice deficient in either caspase-3 (Kuida et al., 1996) or caspase-9 (Hakem et al., 1998; Kuida et al., 1998).

It is not clear why caspases are not coupled more closely to cell death in postnatal neurons cultured under these conditions or in some in vivo systems (Bergeron et al., 1998). One might hypothesize that a caspase-mediated mechanism of cell death provides no additional benefit to a mature nervous system in which neurons must survive throughout the lifetime of the organism. Caspases may be assigned to more specialized tasks that are relevant only in mature neurons.

The present study suggests that caspase-independent pathways may contribute to the death of postnatal neurons after injury. Indeed, there is increasing evidence that caspases may not always be central to the process of cell death. In this regard, Miller et al. (1997) also have postulated a caspase-independent mechanism of programmed cell death in neurons on the basis of the finding that caspase inhibition had only a marginal effect on the survival of postnatal cerebellar granule neurons after potassium withdrawal. The proapoptotic protein, Bax, has been reported to be capable of killing cells independently of caspase activation (J. G. Xiang et al., 1996; Miller et al., 1997). In addition, other studies indicate that caspase inhibition postpones, but does not prevent, cell death, again suggesting the existence of caspase-independent mechanisms of programmed cell death (McCarthy et al., 1997; Bergeron et al., 1998; Kim et al., 1998; Vercammen et al., 1998).

In summary, the results of the present study indicate that the relative importance of specific cell death signaling pathways in neurons may change in accordance with developmental status and the specific nature of the death stimulus. Caspase-dependent cell death pathways that are activated during development may be relegated to a different role in the postdevelopmental period. Caspase-independent pathways, including those mediated by $\mathrm{p} 53$ and Bax, may play a fundamental role in regulating neuronal cell death after acute injury or in neurodegenerative diseases. The role of caspase expression in mature neurons is not understood. Future studies will determine whether caspases also are involved 
in regulating neuronal architecture, synaptic function, or other neuronal properties.

\section{REFERENCES}

Ashkenas J, Werb Z (1996) Proteolysis and the biochemistry of life-ordeath decisions. J Exp Med 183:1947-1951.

Barr D, Tubb J, Ferguson D, Scaria A, Lieber A, Wilson C, Perkins J, Kay MA (1995) Strain-related variations in adenovirally mediated transgene expression from mouse hepatocytes in vivo: comparisons between immunocompetent and immunodeficient inbred strains. Gene Ther 2:151-155.

Bennet M, Macdonald K, Chan S-W, Luzio JP, Simari R, Weissberg P (1998) Cell surface trafficking of Fas: a rapid mechanism of p53mediated apoptosis. Science 282:290-293.

Bergeron L, Perez GI, Macdonald G, Shi L, Sun Y, Jurisicova A, Varmuza S, Latham KE, Flaws JA, Salter JCM, Hara H, Moskowitz MA, Li E, Greenberg A, Tilly JL, Yuan J (1998) Defects in regulation of apoptosis in caspase-2-deficient mice. Genes Dev 12:1304-1314.

Bhat RV, DiRocco R, Marcy VR, Flood DG, Zhu Y, Dobrzanski P, Siman R, Scott R, Contreras PC, Miller M (1996) Increased expression of IL- $1 \beta$ converting enzyme in hippocampus after ischemia: selective localization in microglia. J Neurosci 16:4146-4154.

Brewer GJ, Torricelli JR, Evege EK, Price PJ (1993) Optimized survival of hippocampal neurons in B27-supplemented neurobasal, a new serum-free medium combination. J Neurosci Res 35:567-576.

Cheng Y, Deshmukh M, D'Costa A, Demaro JA, Gidday JM, Shah A, Sun Y, Jacquin MF, Johnson EM, Holtzman DM (1998) Caspase inhibitor affords neuroprotection with delayed administration in a rat model of neonatal hypoxic-ischemic brain injury. J Clin Invest 101:1992-1999.

Cohen GM (1997) Caspases: the executioners of apoptosis. Biochem J 326:1-16.

Cryns V, Yuan JY (1998) Proteases to die for. Genes Dev 12:1551-1570.

de la Monte SM, Sohn YK, Ganju N, Wands JR (1998) p53- and CD95associated apoptosis in neurodegenerative diseases. Lab Invest 78:401-411.

Deshmukh M, Vasilakos J, Deckwerth TL, Lampe PA, Shivers BD, Johnson Jr EM (1996) Genetic and metabolic status of NGF-deprived sympathetic neurons saved by an inhibitor of ICE family proteases. J Cell Biol 135:1341-1354.

Ding H-F, McGill G, Rowan S, Schmaltz C, Shimamura A, Fisher DE (1998) Oncogene-dependent regulation of caspase activation by $\mathrm{p} 53$ protein in a cell free system. J Biol Chem 273:28378-28391.

Donehower LA, Harvey M, Slagle BL, McArthur MJ, Montgomery Jr CA, Butel JS, Bradley A (1992) Mice deficient for p53 are developmentally normal but susceptible to spontaneous tumours. Nature 356:215-221.

Du Y, Bales KR, Dodel RC, Hamilton-Byrd E, Horn JW, Czilli DL, Simmons LK, Ni B, Paul SM (1997) Activation of a caspase-3-related cysteine protease is required for glutamate-mediated apoptosis of cultured cerebellar granule neurons. Proc Natl Acad Sci USA 94:11657-11662.

Eldadah BA, Yakovlev AG, Faden AI (1997) The role of CED-3-related cysteine proteases in apoptosis of cerebellar granule cells. J Neurosci 17:6105-6113.

Eliasson MJL, Sampei K, Mandir AS, Hurn PD, Traystman RJ, Bao J, Pieper A, Wang ZQ, Dawson TM, Snyder SH, Dawson VL (1997) Poly(ADP-ribose) polymerase gene disruption renders mice resistant to cerebral ischemia. Nat Med 3:1089-1095.

Endres M, Wang ZQ, Namura S, Waeber C, Moskowitz MA (1997) Ischemic brain injury is mediated by the activation of poly(ADP-ribose) polymerase. J Cereb Blood Flow Metab 17:1143-1151.

Friedlander RM, Brown RH, Gagliardini V, Wang J, Yuan J (1997a) Inhibition of ICE slows ALS in mice. Nature 388:31.

Friedlander RM, Gagliardini V, Hara H, Fink KB, Li W, MacDonald G, Fishman MC, Greenberg AH, Moskowitz MA, Yuan J (1997b) Expression of a dominant negative mutant of interleukin-1 $\beta$-converting enzyme in transgenic mice prevents neuronal cell death induced by trophic factor withdrawal and ischemic brain injury. J Exp Med 185:933-940.

Gagliardini V, Fernandez PA, Lee RKK, Drexler HCA, Rotello RJ, Fishman MC, Yuan J (1994) Prevention of vertebrate neuronal death by the $\mathrm{crmA}$ gene. Science 263:826-828.

Garcia-Calvo M, Peterson EP, Leiting B, Ruel R, Nicholson DW, Thorn- berry NA (1998) Inhibition of human caspases by peptide-based and macromolecular inhibitors. J Biol Chem 273:32608-32613.

Goldberg YP, Nicholson DW, Rasper DM, Kalchman MA, Koide HB, Graham RK, Bromm M, Kazemi-Esfarjani P, Thornberry NA, Vaillancourt JP, Hayden MR (1996) Cleavage of huntingtin by apopain, a proapoptotic cysteine protease, is modulated by the polyglutamine tract. Nat Genet 13:442-449.

Gottlieb E, Oren M (1998) p53 facilitates pRb cleavage in IL-3-deprived cells: novel pro-apoptotic activity of p53. EMBO J 17:3587-3596.

Gottron FJ, Ying HS, Choi DW (1997) Caspase inhibition selectively reduces the apoptotic component of oxygen-glucose deprivationinduced cortical neuronal cell death. Mol Cell Neurosci 9:159-169.

Hakem R, Hakem A, Duncan GS, Henderson JT, Woo M, Soengas MS, Elia A, de la Pompa JL, Kagi D, Khoo W, Potter J, Yoshida R, Kaufman SA, Lowe SW, Penninger JM, Mak TW (1998) Differential requirement for caspase-9 in apoptotic pathways in vivo. Cell 94:339-352.

Hara H, Fink K, Endres M, Friedlander RM, Gagliardini V, Yuan J, Moskowitz MA (1997a) Attenuation of transient focal cerebral ischemic injury in transgenic mice expressing a mutant ICE inhibitory protein. J Cereb Blood Flow Metab 17:370-375.

Hara H, Friedlander RM, Gagliardini V, Ayata C, Fink K, Huang Z, Shimizu-Sasamata M, Yuan J, Moskowitz MA (1997b) Inhibition of interleukin- $1 \beta$-converting enzyme family proteases reduces ischemic and excitotoxic neuronal damage. Proc Natl Acad Sci USA 94:2007-2012.

Himi T, Ishizaki Y, Murota S (1998) A caspase inhibitor blocks ischaemia-induced delayed neuronal death in the gerbil. Eur J Neurosci 10:777-781.

Jacobson MD, Weil M, Raff MC (1996) Role of ced-3/ICE-family proteases in staurosporine-induced programmed cell death. J Cell Biol 133:1041-1051.

Janicke RU, Sprengart ML, Wati MR, Porter AG (1998) Caspase-3 is required for DNA fragmentation and morphological changes associated with apoptosis. J Biol Chem 273:9357-9360.

Johnson MD, Xiang H, London S, Kinoshita Y, Knudson M, Mayberg M, Korsmeyer SJ, Morrison RS (1998) Evidence for involvement of Bax and $\mathrm{p} 53$, but not caspases, in radiation-induced cell death of cultured postnatal hippocampal neurons. J Neurosci Res 54:721-733.

Jordan J, Galindo MF, Miller RJ (1997a) Role of calpain- and interleukin- $1 \beta$-converting enzyme-like proteases in the $\beta$-amyloidinduced death of rat hippocampal neurons in culture. J Neurochem 68:1612-1621.

Jordan J, Galindo MF, Prehn JH, Weichselbaum RR, Beckett M, Ghadge GD, Roos RP, Leiden JM, Miller RJ (1997b) p53 expression induces apoptosis in hippocampal pyramidal neuron cultures. J Neurosci 17:1397-1405.

Kanegae Y, Lee G, Sato Y, Tanaka M, Nakai M, Sakaki T, Sugano S, Saito I (1995) Efficient gene activation in mammalian cells by using recombinant adenovirus expressing site-specific Cre recombinase. $\mathrm{Nu}$ cleic Acids Res 23:3816-3821.

Keane RW, Srinivasan A, Foster LM, Testa M-P, Ord T, Nonner D, Wang H-G, Reed JC, Bredesen DE, Kayalar C (1997) Activation of CPP32 during apoptosis of neurons and astrocytes. J Neurosci Res 48:168-180.

Kim K, Lee CK, Sayers TJ, Muegge K, Durum SK (1998) The trophic action of IL-7 on pro-T cells: inhibition of apoptosis of pro-T1, -T2, and -T3 cells correlates with Bcl-2 and Bax levels and is independent of Fas and p53 pathways. J Immunol 160:5735-5741.

Krajewska M, Wang H-G, Krajewski S, Zapata JM, Shabaik A, Gascoyne $\mathrm{R}$, Reed JC (1997) Immunohistochemical analysis of in vivo patterns of expression of CPP32 (caspase-3), a cell death protease. Cancer Res 57:1605-1613.

Kuida K, Lippke JA, Ku G, Harding MW, Livingston DJ, Su MS, Flavell RA (1995) Altered cytokine export and apoptosis in mice deficient in interleukin-1 $\beta$-converting enzyme. Science 267:2000-2006.

Kuida K, Zheng TS, Na S, Kuan C-Y, Yang D, Karasuyama H, Rakic P, Flavell RA (1996) Decreased apoptosis in the brain and premature lethality in CPP32-deficient mice. Nature 384:368-372.

Kuida K, Haydar TF, Kuan CY, Gu Y, Taya C, Karasuyama H, Su MS, Rakic P, Flavell RA (1998) Reduced apoptosis and cytochrome $\mathrm{C}$-mediated caspase activation in mice lacking caspase-9. Cell 94:325-337.

Kumar S, Kinoshita M, Noda M, Copeland NG, Jenkins NA (1994) Induction of apoptosis by the mouse $N e d d 2$ gene, which encodes a 
protein similar to the product of the Caenorhabditis elegans cell death gene ced-3 and the mammalian IL- $1 \beta$-converting enzyme. Genes Dev 8:1613-1626.

Loddick SA, MacKenzie A, Rothwell NJ (1996) An ICE inhibitor $\mathrm{Z}$-VAD-DCB attenuates ischaemic brain damage in the rat. NeuroReport 7:1465-1468.

Lynch T, Vasilakos JP, Raser K, Keane KM, Shivers BD (1997) Inhibition of the interleukin- $\beta$-converting enzyme family rescues neurons from apoptotic death. Mol Psychol 2:227-238.

Martinou I, Fernandez PA, Missotten M, White E, Allet B, Sadoul R, Martinou JC (1995) Viral proteins E1B19K and p35 protect sympathetic neurons from cell death induced by NGF deprivation. J Cell Biol 128:201-208.

Martinou I, Missotten M, Fernandez PA, Sadoul R, Martinou JC (1998) Bax and Bak proteins require caspase activity to trigger apoptosis in sympathetic neurons. NeuroReport 9:15-19.

Marzo I, Brenner C, Zamzami N, Jurgensmeier JM, Susin SA, Vieira HLA, Prevost MC, Xie Z, Matsuyama S, Reed JC, Kroemer G (1998) Bax and adenine nucleotide translocator cooperate in the mitochondrial control of apoptosis. Science 281:2027-2031.

McCarthy NJ, Whyte MKB, Gilbert C, Evan G (1997) Inhibition of ced-3/ICE-related proteases does not prevent cell death induced by oncogenes, DNA damage, or the Bcl-2 homologue Bak. J Cell Biol $136: 215-227$.

Miller TM, Moulder KL, Knudson CM, Creedon DJ, Deshmukh M, Korsmeyer SJ, Johnson EM (1997) Bax deletion further orders the cell death pathway in cerebellar granule cells and suggests a caspaseindependent pathway to cell death. J Cell Biol 139:205-217.

Milligan CE, Prevette D, Yaginuma H, Homma S, Cardwell C, Fritz LC, Tomaselli KJ, Oppenheim RW, Schwartz LM (1995) Peptide inhibitors of the ICE protease family arrest programmed cell death of motoneurons in vivo and in vitro. Neuron 15:385-393.

Morrison RS, de Vellis J (1981) Growth of purified astrocytes in a chemically defined medium. Proc Natl Acad Sci USA 78:7205-7209.

Morrison RS, Wenzel HJ, Kinoshita Y, Robbins CA, Donehower LA, Schwartzkroin PA (1996) Loss of the p53 tumor suppressor gene protects neurons from kainate-induced cell death. J Neurosci 16:1337-1345.

Namura S, Zhu J, Fink K, Endres M, Srinivasan A, Tomaselli KJ, Yuan J, Moskowitz MA (1998) Activation and cleavage of caspase-3 in apoptosis induced by experimental cerebral ischemia. J Neurosci 18:3659-3668.

Nath R, Raser KJ, McGinnis K, Nadimpalli R, Stafford D, Wang KK (1996) Effects of ICE-like protease and calpain inhibitors on neuronal apoptosis. NeuroReport 8:249-255.

Ni B, Wu X, Du Y, Su Y, Hamilton-Byrd E, Rockey PK, Rosteck Jr P, Poirier GG, Paul SM (1997) Cloning and expression of a rat brain interleukin-1 $\beta$-converting enzyme (ICE)-related protease (IRP) and its possible role in apoptosis of cultured cerebellar granule neurons. J Neurosci 17:1561-1569.

Nicholson DW, Thornberry NA (1997) Caspases: killer proteases. Trends Biochem Sci 22:299-306.

Owen-Schaub LB, Zhang W, Cusack JC, Angelo LS, Santee SM, Fujiwara T, Roth JA, Deisseroth AB, Zhang W-W, Kruzel E, Radinsky R (1995) Wild-type human p53 and a temperature-sensitive mutant induce Fas/APO-1 expression. Mol Cell Biol 15:3032-3040.

Porter AG, Ng P, Janicke RU (1997) Death substrates come alive. BioEssays 19:501-507.

Posmantur R, McGinnis K, Nadimpalli, Gilbertsen RB, Wang KKW (1997) Characterization of CPP32-like protease activity following apoptotic challenge in SH-SY5Y neuroblastoma cells. J Neurochem 68:2328-2337.

Prehn JHM, Jordan J, Ghadge GD, Preis E, Galindo MF, Roos RP, Krieglstein J, Miller RJ (1997) $\mathrm{Ca}^{2+}$ and reactive oxygen species in staurosporine-induced neuronal apoptosis. $\mathrm{J}$ Neurochem 68:1679-1685.

Rabizadeh S, LaCount DJ, Friesen PD, Bredesen DE (1993) Expression of the baculovirus p35 gene inhibits mammalian neural cell death. J Neurochem 61:2318-2321.

Reed JC (1997) Double identity for proteins of the Bcl-2 family. Nature 387:773-776.
Sakurai M, Hayashi T, Abe K, Sahahiro M, Tabayashi K (1998) Delayed selective motor neuron death and Fas antigen induction after spinal cord ischemia in rabbits. Brain Res 797:23-28.

Schielke GP, Yang GY, Shivers BD, Betz AL (1998) Reduced ischemic brain injury in interleukin-1 $\beta$-converting enzyme-deficient mice. J Cereb Blood Flow Metab 18:180-185.

Schulz JB, Weller M, Klockgether T (1996) Potassium deprivationinduced apoptosis of cerebellar granule neurons: a sequential requirement for new mRNA and protein synthesis, ICE-like protease activity, and reactive oxygen species. J Neurosci 16:4696-4706.

Shin SW, Park JW, Suh MH, Suh SI, Choe BK (1998) Persistent expression of Fas/FasL mRNA in the mouse hippocampus after a single NMDA injection. J Neurochem 71:1773-1776.

Slack RS, Belliveau DJ, Rosenberg M, Atwal J, Lochmuller H, Aloyz R, Haghighi A, Lach B, Seth P, Cooper E, Miller FD (1996) Adenovirusmediated gene transfer of the tumor suppressor p53 induces apoptosis in postmitotic neurons. J Cell Biol 135:1085-1096.

Takahashi K, Greenberg JH, Jackson P, Maclin K, Zhang J (1997) Neuroprotective effects of inhibiting poly(ADP-ribose) synthetase on focal cerebral ischemia in rats. J Cereb Blood Flow Metab 17:1137-1142.

Tenneti L, D'Emilia DM, Troy CM, Lipton SA (1998) Role of caspases in $N$-methyl-D-aspartate-induced apoptosis in cerebrocortical neurons. J Neurochem 71:946-959.

Timme T, Thompson TC (1994) Rapid allelotype analysis of p53 knockout mice. Biotechniques 17:461-463.

Troy CM, Stefanis L, Greene LA, Shelanski ML (1997) Nedd2 is required for apoptosis after trophic factor withdrawal, but not superoxide dismutase (SOD1) downregulation, in sympathetic neurons and PC12 cells. J Neurosci 17:1911-1918.

Vaziri H, West MD, Allsopp RC, Davison TS, Wu YS, Arrowsmith CH, Poirier GG, Benchimol S (1997) ATM-dependent telomere loss in aging human diploid fibroblasts and DNA damage lead to the posttranslational activation of p53 protein involving poly(ADP-ribose) polymerase. EMBO J 16:6018-6033.

Vekrellis K, McCarthy MJ, Watson A, Whitfield J, Rubin LL, Ham J (1997) Bax promotes neuronal cell death and is downregulated during the development of the nervous system. Development 124:1239-1249.

Vercammen D, Beyaert R, Denecker G, Goossens V, Van-Loo G, Declercq W, Grooten J, Fiers W, Vandenabeele P (1998) Inhibition of caspases increases the sensitivity of L929 cells to necrosis mediated by tumor necrosis factor. J Exp Med 187:1477-1485.

Wellington CL, Ellerby LM, Hackam AS, Margolis RL, Trifiro MA, Singaraja R, McCutcheon K, Salvesen GS, Propp SS, Bromm M, Rowland KJ, Zhang T, Rasper D, Roy S, Thornberry N, Pinsky L, Kakizuka A, Ross CA, Nicholson DW, Bredesen DE, Hayden MR (1998) Caspase cleavage of gene products associated with triplet expansion disorders generates truncated fragments containing the polyglutamine tract. J Biol Chem 273:9158-9167.

Whitacre CM, Hashimoto H, Min-Lung T, Chatterjee S, Berger SJ, Berger NA (1995) Involvement of NAD-poly(ADP-ribose) metabolism in p53 regulation and its consequences. Cancer Res 55:3697-3701.

Wiesner DA, Dawson G (1996) Staurosporine induces programmed cell death in embryonic neurons and activation of the ceramide pathway. J Neurochem 66:1418-1425.

Xiang H, Hochman DW, Saya H, Fujiwara T, Schwartzkroin PA, Morrison RS (1996) Evidence for p53 modulation of neuronal viability. J Neurosci 16:6753-6765.

Xiang H, Kinoshita Y, Knudson CM, Korsmeyer SJ, Schwartzkroin PA, Morrison RS (1998) Bax involvement in p53-mediated neuronal cell death. J Neurosci 18:1363-1373.

Xiang JG, Chao DT, Korsmeyer SJ (1996) BAX-induced cell death may not require interleukin-1 $\beta$-converting enzyme-like proteases. Proc Natl Acad Sci USA 93:14559-14563.

Yakovlev AG, Knoblach SM, Fan L, Fox GB, Goodnight R, Faden AI (1997) Activation of CPP32-like caspases contributes to neuronal apoptosis and neurological dysfunction after traumatic brain injury. J Neurosci 17:7415-7424.

Zhang WW, Fang X, Branch CD, Mazur W, French BA, Roth JA (1993) Generation and identification of recombinant adenovirus by liposomemediated transfection and PCR analysis. Biotechniques 15:868-872. 